\title{
Condition factor of Astyanax intermedius Eigenmann, 1908 (OSTEICHTHYES, CHARACIDAE) parasitised by Paracymothoa astyanaxi Lemos de Castro, 1955 (CRUSTACEA, CYMOTHOIDAE) in the Grande River, Serra do Mar State Park - Santa Virgínia Unit, São Paulo, Brazil
}

\author{
Gomiero, LM. ${ }^{a *}$, Souza, UP. ${ }^{b}$ and Braga, FMS. ${ }^{a}$ \\ aDepartment of Zoology, Universidade Estadual Paulista - UNESP, \\ Av. 24-A, 1515, CP 199, CEP 13506-900, Rio Claro, SP, Brazil \\ bDepartment of Ecology, Universidade Estadual Paulista - UNESP, \\ Av. 24-A, 1515, CP 199, CEP 13506-900, Rio Claro, SP, Brazil \\ *e-mail: 1mullergomiero@yahoo.com.br
}

Received March 30, 2011 - Accepted June 30, 2011 - Distributed May 31, 2012

(With 8 figures)

\begin{abstract}
In this work the length-weight relationship and the condition factor of Astyanax intermedius parasitised and not by Paracymothoa astyanaxi were analysed in the Grande River. The length-weight relationship was estimated for females, males and immatures, and seasonally for the fishes and the parasites through the expression $\mathrm{W}=\mathrm{aL}^{\mathrm{b}}$. The condition factor of non-parasitised specimens differed seasonally and between sexes, contrasting with the results for parasitised fishes which showed no differences between sexes and season. The condition factor of non-parasitised specimens was higher than that of the parasitised fishes. Specimens of Astyanax intermedius parasitised do not have the same biotic conditions compared to non-parasitised individuals, in which the condition factor was similar over the years. In conclusion, parasitism by $P$. astyanaxi has deleterious effects on this host population which may cause changes in the reproductive and food dynamics of parasitised specimens due to low body conditions.
\end{abstract}

Keywords: parasitism, condition factor, length-weight relationship.

Fator de condição de Astyanax intermedius Eigenmann, 1908

(OSTEICHTHYES, CHARACIDAE) parasitados por Paracymothoa astyanaxi

Lemos de Castro, 1955 (CRUSTACEA, CYMOTHOIDAE) no Rio Grande, Núcleo Santa Virgínia, Parque Estadual da Serra do Mar, São Paulo, Brasil

\begin{abstract}
Resumo
Foram analisados a relação peso-comprimento e o fator de condição de Astyanax intermedius parasitados ou não pelo isópode Paracymothoa astyanaxi. A relação peso-comprimento foi estimada para fêmeas, machos e imaturos, e sazonalmente tanto para os peixes quanto para o parasito, por meio da expressão $\mathrm{P}=\mathrm{aC}^{\mathrm{b}}$. $\mathrm{O}$ fator de condição dos exemplares não parasitados diferiu sazonalmente e entre os sexos, contrastando com os valores do fator de condição dos peixes parasitados, que não apresentaram diferenças sazonais e entre os sexos. O fator de condição dos exemplares não parasitados foi sempre maior do que o dos exemplares parasitados. Os exemplares de Astyanax intermedius parasitados não passaram pelas mesmas condições bióticas dos indivíduos não parasitados, apresentando um fator de condição semelhante ao longo do ano. Conclui-se que o parasitismo por $P$. astyanaxi atua de forma deletéria na população desse hospedeiro, podendo causar alterações nas dinâmicas reprodutiva e alimentar dos exemplares parasitados em razão da baixa condição corpórea.
\end{abstract}

Palavras-chave: parasitismo, fator de condição, relação peso-comprimento. 


\section{Introduction}

Based on the morphology and karyotipe differences, Moreira-Filho and Bertollo (1991) categorised the populations of Astyanax scabripinnis (Eigenmann, 1914) as the "scabripinnis complex". Nowadays, 15 species are recognised, including Astyanax intermedius Eigenmann, 1908 (Bertaco and Lucena, 2006). This species is an interesting biological material in studies of natural populations due to their peculiar characteristics of limited distribution at the headwaters of many watersheds in Brazil (Souza and Moreira-Filho, 1995). In the Grande River, 10 species were sampled, being $A$. intermedius the most abundant and constant (Gomiero and Braga, 2006). The "lambaris" are food for species of large fish, mammals, reptiles and ichthyophagous birds and therefore have an important role in the food chain, and are associated with submerged vegetation for both food and shelter (Vilella et al., 2002). The macrophyte community harbours a fauna characterised by small species or juveniles of larger fish, and these habitats provide shelter and places for food (Delariva et al., 1994).

Fishes have a greater quantity and variety of parasites than any other class of vertebrates, and this occurs due to the long period of time living in association with a variety of forms of invertebrates (Thatcher, 1991). In natural ecosystems, they are always found with infestations of parasites and studies are needed concerning the influence of these parasites, even more because most research has been done in the laboratory (Barber et al., 2000). Therefore, due to the lack of studies on the effects of macroparasites in teleost hosts, changes in fitness have rarely been quantified, and their ecological and evolutionary meanings are unknown. The possible effects of pathogens (parasites) on their hosts are difficult to assess or quantify, especially in fish under natural conditions, where the difficulty lies in the definition of the control group that can compare individuals parasitised (Yamada et al., 2008). The parasite infestations can cause changes in the efficiency of foraging, habitat selection, competitive ability, predator-prey relationships, swimming performance, mate choice and sexual behaviour (Barber et al., 2000).

The isopod parasites have no important morphological changes; except for the anterior prehensile appendages and adaptation of the armor oral to feed, its morphology is quite similar to the free living forms. Cymothoidae are typically hemophagous parasites. However, the supply to the largesized females in the oral cavity is unknown and it has been suggested that some species are commensal (Eiras, 1994). Males of Cymothoidae are always smaller than females (Thatcher, 1993), copulation and insemination was still occurring in the host (Brusca, 1978). For some species, no male was found with females showing reproductive larvae in its chambers (marsupials), which suggests that these small males go for the environment and may die after fertilising the females (Bastos and Thatcher, 1997). Pregnant females are more frequent in the months with higher temperatures (Brusca and Gilligan, 1983).
Paracymothoa astyanaxi Lemos de Castro (1955) was described as parasites of the mouth of Astyanax bimaculatus (Linnaeus, 1758) on the River das Pedras (RJ) and River Matipó (MG). Pregnant females of the parasite have the characteristic of presenting the posterior pleopods as the stylets of males, which indicates that they are protandrous hermaphrodites (Lemos de Castro, 1955), reaching the hosts as males, but after a short period of free life as juveniles, later transforming themselves into females in the gills or mouth (Eiras, 1994). Transferrals of parasites to different hosts seems to be common (Varvarigos, 2003), which may have occurred in the same living environment of A. bimaculatus and Astyanax intermedius. The behaviour of school fish favours direct transmission of parasites (Barber et al., 2000; Tavares and Luque, 2004).

This parasite causes the degeneration or atrophy of the tongue by pressure (Thatcher, 1991) and is clamped by the pereopods replacing functionally and mechanically the tongue and it grows with the hosts (Brusca and Gilligan, 1983; Eiras, 1994). Parasites in the oral region weaken the host and facilitate their predation (Abdallah et al., 2004). Moreover, Moreira et al. (2005) observed that parasitism had no influence on the condition factor of Iheringichthys labrosus (Lütken, 1874). Parasitism can prolong the life of the host by channelling reproductive investment for growth and maintenance (Lima et al., 2007). However, adverse effects and death can occur in young or smaller hosts, while the greatest changes can occur in body condition (Varvarigos, 2003).

The aim of this study is to characterise and compare the length-weight relationship and condition factor by sex and seasonally of Astyanax intermedius parasitised and not parasitised by Paracymothoa astyanaxi. The lengthweight relationship and seasonal condition factor of the parasite were also characterised.

\section{Material and Methods}

A total of 24 samples were taken monthly from January to December 2004 and 2006. The river is typical hillside streams, which have riparian forest in regenerations, pools and riffles, bed sediments of sand, gravel or rock, and clear shallow water. In areas of the collections macrophyte banks of the Potamogeton polygonus Chamess. and Schltdl. and Juncus sp. were always present, and in these places, concentrated schools of $A$. intermedius were found. The site is located within the Santa Virgínia Unit of the Serra do Mar State Park (23 $17^{\circ} \mathrm{S}$ and $\left.45^{\circ} 03^{\prime} \mathrm{W}\right)$, in the municipality of São Luís do Paraitinga, São Paulo state, Brazil. At each sample point, individuals were collected with gill nets with mesh sizes of $1.5 ; 2.0 ; 2.5 ; 3.0 ; 3.5$, and $4.0 \mathrm{~cm}$, measured between adjacent knots $(10 \mathrm{~m}$ long and $1.5 \mathrm{~m}$ high), and totalling $60 \mathrm{~m}$. In addition to the nets, sieves (10 passages per site), and traps (three per site) were also used. Fish effort was standardised, keeping constant sampling time and the quantity of instruments employed at each point. Voucher specimens are deposited in the fish collection of Universidade Federal do Rio Grande do 
Sul, Porto Alegre (UFRGS 10821). For each specimen of Astyanax intermedius and of the parasites, the total weight $(\mathrm{g})$, the total length $(\mathrm{cm})$ and sex were taken. The immature fishes were determined by visualisation of the gonads macroscopically, considering colouration, transparency, and superficial vascularisation. Males and females were determined with visualisation of the gonads in colour, shape and presence of sperm or oocytes, respectively (Braga, 1990). For parasites, the females were determined by the larger size as compared to males and by visualisation of eggs or embryos in the marsupium.

Numerical frequencies in the classes of total length of females and males of A. intermedius parasitised and not were analysed with the Kolmogorov-Smirnov test (Vanzolini, 1993), as well as the numerical distribution in classes of total length of females and males of the parasite Paracymothoa astyanaxi.

The condition factor for fish without parasites and parasitised was estimated initially using length-weight relationship $\left(\mathrm{W}=\mathrm{aL}^{\mathrm{b}}\right)$, after logarithmic transformation of length and weight and subsequent adjustment of two straight lines, obtaining $\ln y=\ln A+B \ln x$ that the method of least squares obtain A and B from which $a=e^{A}, b=B$ (Santos, 1978; Braga, 1986) is calculated. The straight lines estimated were tested among themselves with regard to slope (b) and intercept (a).

The mean and standard deviation of the condition factor for females, males and immature of parasitised and non-parasitised A. intermedius were obtained. For the parasites, the length-weight relationship and the mean values and standard deviations of the seasonal condition factor were presented. The non-parametric Kruskal-Wallis test followed by an a posteriori Tukey test (Zar, 2010) was applied to check the correspondence of the seasonal condition factor for parasitised and non-parasitised fish, the groups of females, males, and immatures, and the seasonal condition factor of the parasites.

\section{Results}

Some anatomical changes mainly in the oral region were observed in individuals of $A$. intermedius without parasites and those parasitised (Figure 1).

The parasite Paracymothoa astyanaxi presents the typical morphology of the family Cymothoidae with the latest pereopods adapted for grasping in the oral region of the fish host (Figure 2).

In 24 samples, 1073 specimens of Astyanax intermedius without parasites constituted by 282 females, 334 males and 457 immatures, and 172 parasitised specimens, made up of 60 females, 66 males and 46 immatures, were collected and analyzed. Astyanax intermedius without parasites reached total lengths of 2 to $10.3 \mathrm{~cm}$, females 3.6 to $10.3 \mathrm{~cm}$, males from 4 to $9.3 \mathrm{~cm}$ and immatures, 2 to $6.4 \mathrm{~cm}$. Parasitised fishes reached total lengths of 2.3 to $9.3 \mathrm{~cm}$, with females from 5 to $9.3 \mathrm{~cm}$, males 3.5 to $8.6 \mathrm{~cm}$ and immatures from 2.3 to $8 \mathrm{~cm}$ (Figure 3). There was a difference $\left(\chi^{2}=152.59 ; \mathrm{p}<0.001\right)$ between the distributions
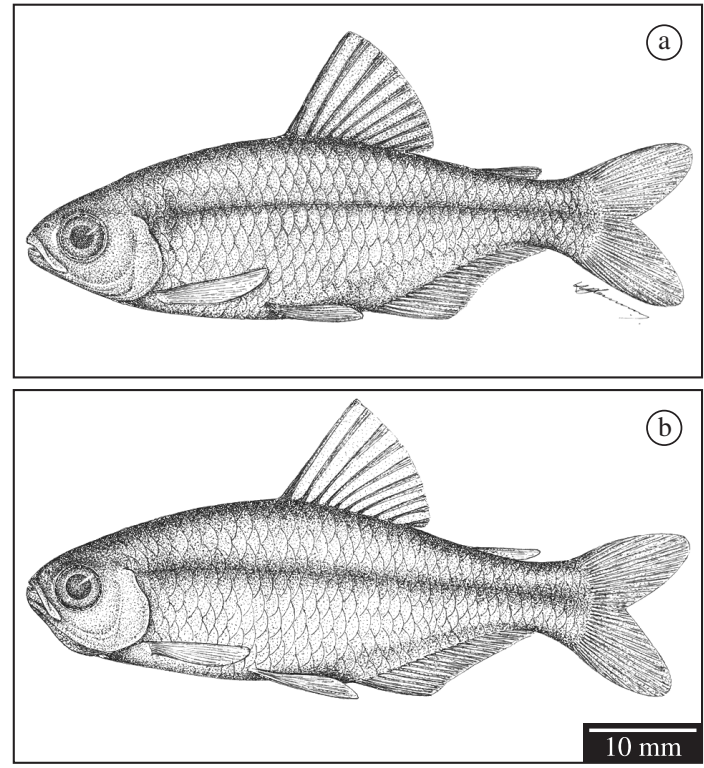

Figure 1. Astyanax intermedius without the parasite in the oral cavity (a) and with the parasite Paracymothoa astyanaxi in the oral cavity (b).


Figure 2. Side view (a), ventral (b) and dorsal (c) of the parasite Paracymothoa astyanaxi (female).

of lengths of females and males of A. intermedius without the parasite. However, no significant difference $\left(\chi^{2}=3.62\right.$; $\mathrm{p}>0.05$ ) between the distributions of lengths of females 


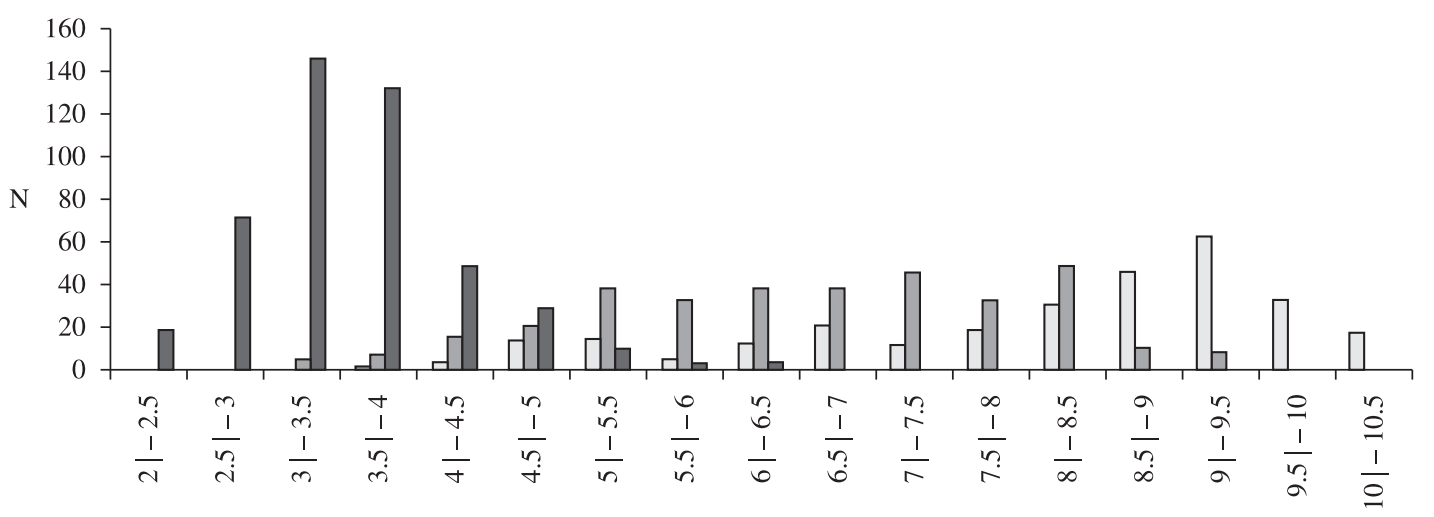

Classes of total length $(\mathrm{cm})$

Parasitised

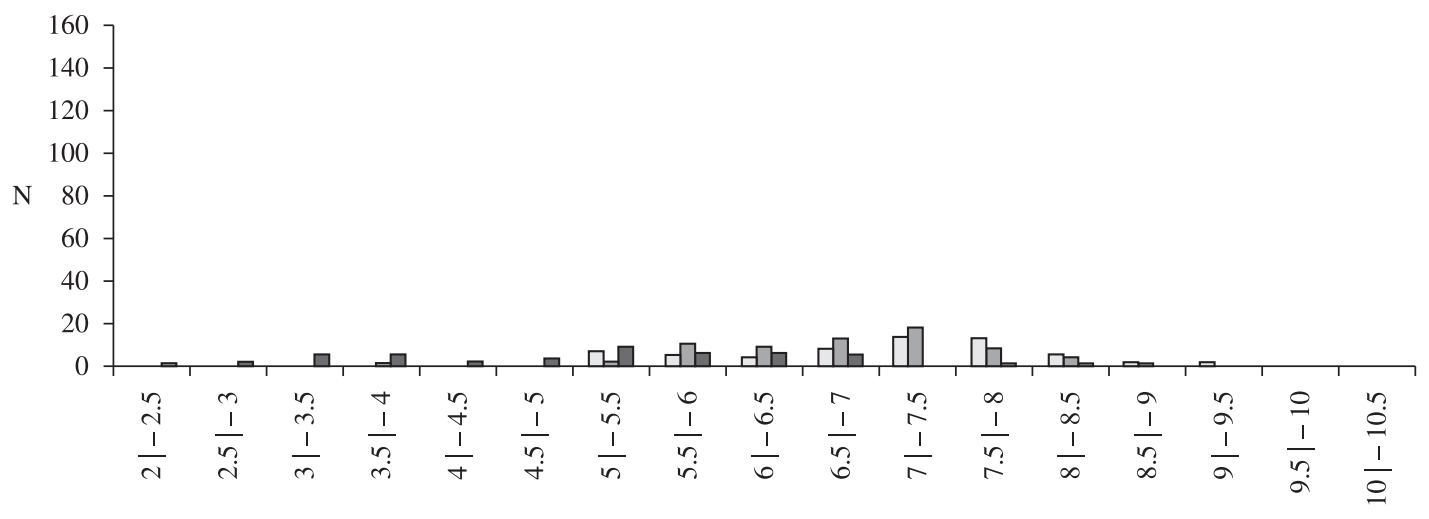

Classes of total length $(\mathrm{cm})$

$\square$ Females $\square$ Males $\square$ Immatures

Figure 3. Numerical frequencies in the classes of total length of females, males and immatures of Astyanax intermedius with no parasites and parasitised by Paracymothoa astyanaxi.

and males parasitised by $P$. astyanaxi. In the distribution of lengths of the parasites, it was verified that the size at which individuals change sex was between 6.5 and $8 \mathrm{~mm}$. Males of $P$. astyanaxi reached total lengths of 3 to $8 \mathrm{~mm}$ and females were 6.5 to $11.7 \mathrm{~mm}$ (Figure 4). Significant differences in the frequency distributions of lengths of females and males was found $\left(\chi^{2}=62.32 ; \mathrm{p}<0.001\right)$.

The average length of females without parasites and with parasites was higher than that for males. For both the parasitised and non-parasitised fish, the females had higher average weight in relation to males and immatures. However, the average weight of females without parasites was higher than that of females with parasites (Table 1).

In the straight lines obtained from the data of weight and length of non- parasitised and parasitised fish, the variances were heterogeneous $(\mathrm{F}<0.05)$, and in the test between the slopes, it was determined that these are different $(\mathrm{p}<0.05)$. Thus, the lines are distinct and are not parallel, setting different length-weight relationships (Table 2).

The linear regressions and the length-weight relationship of Astyanax intermedius without parasites and parasitised by Paracymothoa astyanaxi with their equations and $\mathrm{r}^{2}$ values (coefficient of determination) are shown in Figure 5. This figure displays that the straight lines and curves relating to the non-parasitised and parasitised fish are different, featuring distinct characteristics for the two groups sampled.

Means and standard deviations for the allometric condition factor were obtained by the season for the specimens of $A$. intermedius with and without parasites (Figure 6). Significant variations were found in the means of seasonal condition factor of A. intermedius without parasites $(\mathrm{H}=122.42 ; \mathrm{p}<0.01)$. For the test a posteriori the average condition factor of winter $(K=0.009374)$ was similar $(\mathrm{p}>0.01)$ to spring $(\mathrm{K}=0.009252)$ and was higher $(\mathrm{p}<0.01)$ than the values for summer $(\mathrm{K}=0.008764)$ and autumn $(\mathrm{K}=0.00832)$. The average condition factor of autumn was lower $(\mathrm{p}<0.01)$ than for summer. Moreover, there was no significant difference in the average seasonal condition factor for specimens of parasitised $A$. intermedius $(\mathrm{H}=0.3738 ; \mathrm{p}>0.01)$.

Means and standard deviations for the allometric condition factor of $A$. intermedius parasitised and not by $P$. astyanaxi were obtained for females, males and 


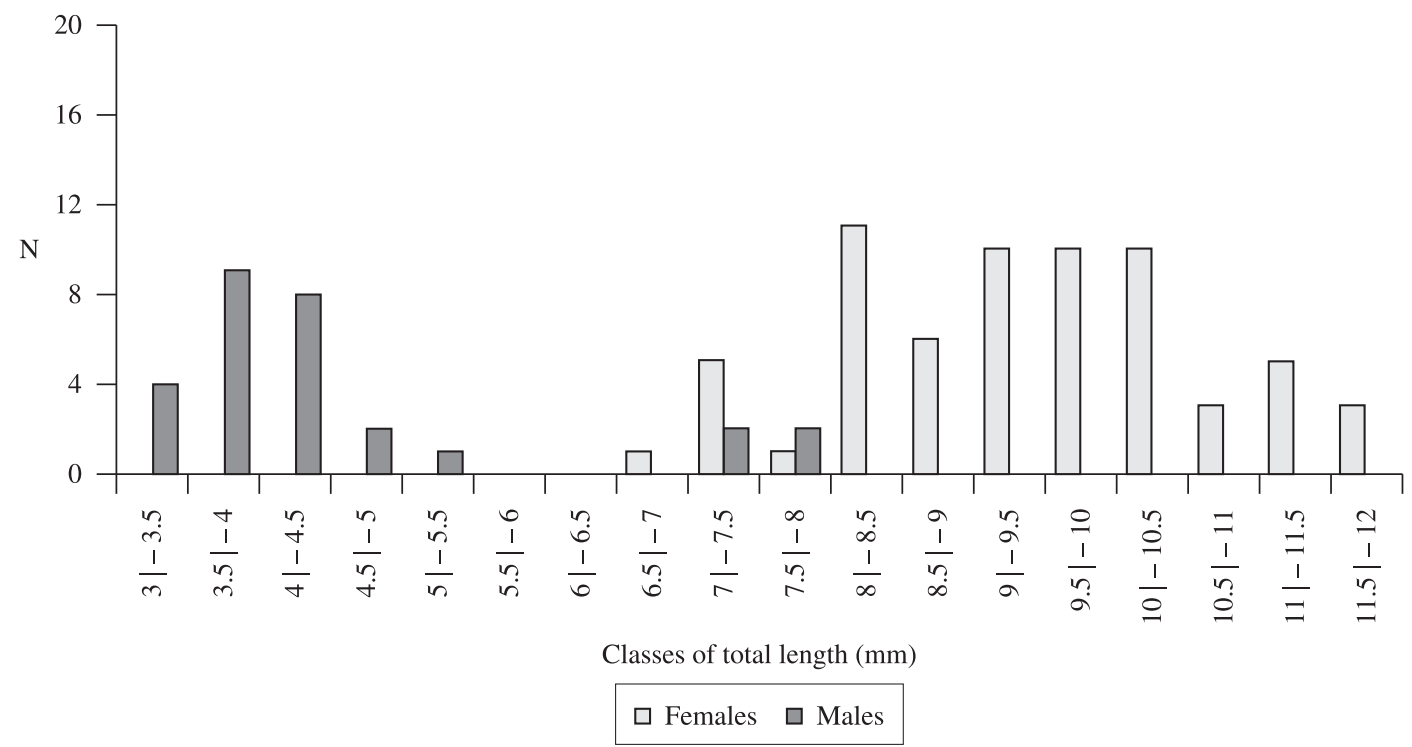

Figure 4. Numerical frequencies in the classes of total length of females and males of the parasite Paracymothoa astyanaxi.

Table 1. Biological data of total weight (TW), average weight (AW) and average length (AL) with the respective errors of the mean for the total, females, males and immatures of Astyanax intermedius with no parasites and parasitised by Paracymothoa astyanaxi.

\begin{tabular}{lcccc}
\hline \multicolumn{1}{c}{ No parasites } & Total & Females & Males & Immature \\
\hline $\mathrm{TW}(\mathrm{g})$ & $3,690.44$ & $2,164.68$ & $1,287.43$ & 238.33 \\
$\mathrm{AW} \pm \mathrm{EM}(\mathrm{g})$ & $3.43 \pm 0.11$ & $7.73 \pm 0.23$ & $3.83 \pm 0.13$ & $0.52 \pm 0.01$ \\
$\mathrm{AL} \pm \mathrm{EM}(\mathrm{cm})$ & $5.66 \pm 0.07$ & $8.13 \pm 0.09$ & $6.56 \pm 0.07$ & $3.49 \pm 0.03$ \\
$\mathrm{~N}$ & 1073 & 282 & 334 & 457 \\
\hline \multicolumn{1}{c}{ Parasitised } & Total & Females & Males & Immature \\
\hline $\mathrm{TW}(\mathrm{g})$ & 551.62 & 245.05 & 234.98 & 71.58 \\
$\mathrm{AW} \pm \mathrm{EM}(\mathrm{g})$ & $3.2 \pm 0.13$ & $4.08 \pm 0.23$ & $3.56 \pm 0.15$ & $1.55 \pm 0.17$ \\
$\mathrm{AL} \pm \mathrm{EM}(\mathrm{cm})$ & $6.38 \pm 0.1$ & $7.02 \pm 0.13$ & $6.75 \pm 0.1$ & $5.01 \pm 0.2$ \\
$\mathrm{~N}$ & 172 & 60 & 66 & 46 \\
\hline
\end{tabular}

Table 2. Parameters of linear regressions concerning the of weight-length relationships of Astyanax intermedius with no parasites and parasitised.

\begin{tabular}{lccccccccc}
\hline Groups/parameters & $\mathbf{A}$ & $\mathbf{B}$ & $\mathbf{a}$ & $\mathbf{b}$ & $\mathbf{T}_{\mathbf{v}}$ & $\mathbf{R}$ & $\mathbf{N}$ & $\mathbf{s}_{\mathbf{y x}}$ & $\mathbf{F}_{\mathbf{0 . 0 5}}$ \\
\hline No parasites & -4.73 & 3.1605 & 0.0088 & 3.1605 & $\mathrm{p}<0.05$ & 0.9958 & 1073 & 1.7615 & $\mathrm{~F}<0.05$ \\
Parasitised & -5.01 & 3.2492 & 0.0066 & 3.2492 & & 0.9872 & 172 & 0.04121 & \\
\hline
\end{tabular}

$\mathbf{A}=\log$. the intercept $\mathbf{B}$ and $\mathbf{b}=$ value of the slope; $\mathbf{a}=$ numeric value of the intercept; $\mathbf{T} \mathbf{v}=$ test result between the slopes with v degrees of freedom calculated when variances are heterogeneous; $\mathbf{R}=$ correlation coefficient; $\mathbf{N}=$ number of data pairs; $\mathbf{s}_{\mathbf{y x}}^{\mathbf{2}}=$ variance of regression; $\mathbf{F}_{\mathbf{0 . 0 5}}=$ result of test of homogeneity of variances.

immatures (Figure 7). A significant variation in the condition factor among groups of females, males and immature without parasites $(\mathrm{H}=25.6 ; \mathrm{p}<0.001)$ was verified. For the a posteriori test, the immatures demonstrated a mean condition factor $(K=0.008967)$ higher $(p<0.01)$ than males $(K=0.008651)$ and similar $(p>0.01)$ than females $(K=0.009017)$. The average value of females was higher $(\mathrm{p}<0.01)$ than those of males. However, there was no significant difference in the mean condition factor among groups of females, males and immatures parasitised $(\mathrm{H}=0.5164 ; \mathrm{p}>0.01)$

In Figure 8, the length-weight relationship of $P$. astyanaxi is presented with its equation of potency function $\left(\mathrm{Y}=\mathrm{aX} \mathrm{X}^{\mathrm{b}}\right)$ and the values of $\mathrm{r}^{2}$ (coefficient of determination), as well as mean values and standard deviations for the seasonal allometric factor condition. There was significant variation in the average seasonal condition factor of $P$. astyanaxi $(H=60.78 ; \mathrm{p}<0.01)$. For the a posteriori test, the average 

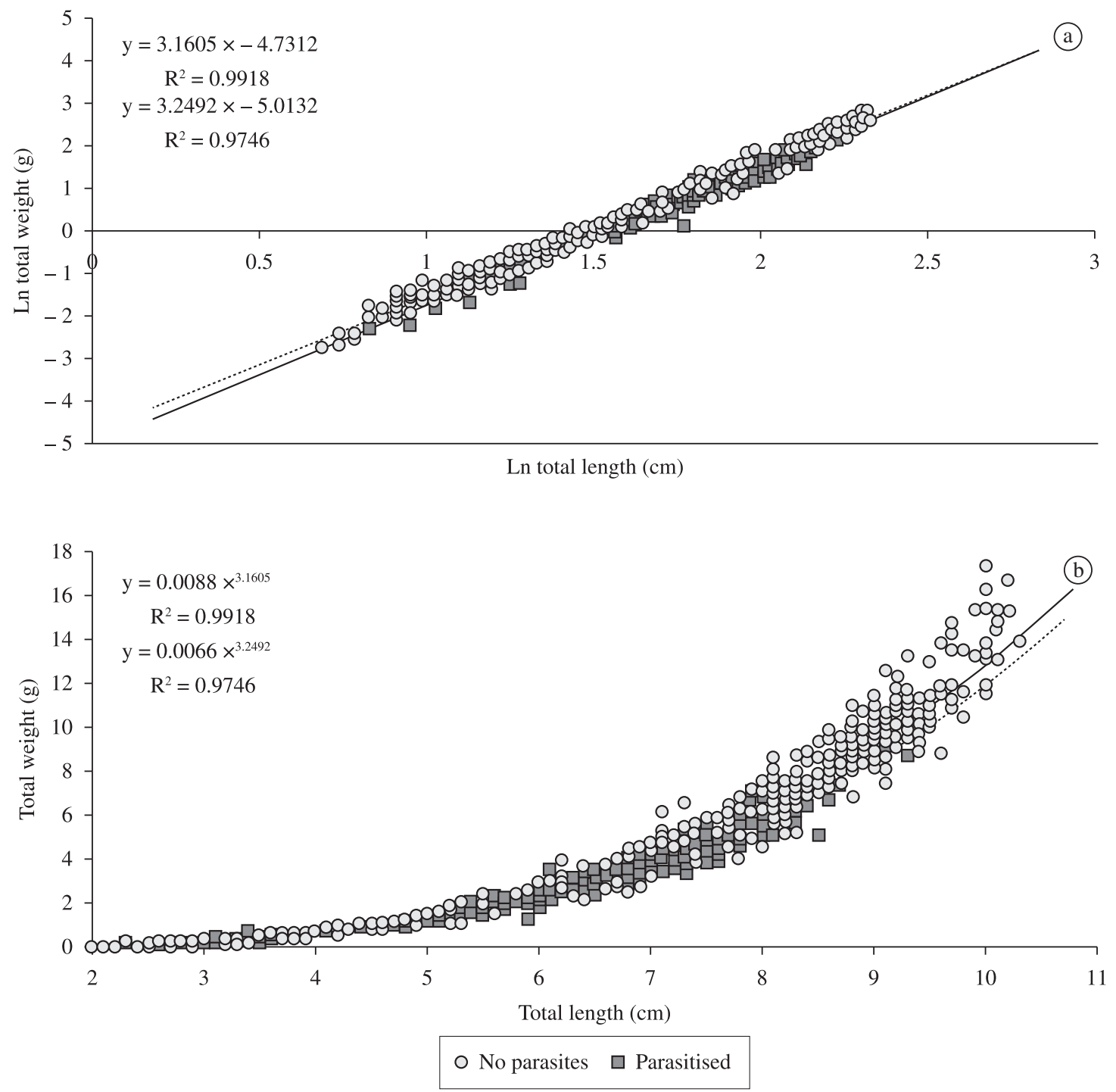

Figure 5. Linear regressions (a) and weight-length relationships (b) of Astyanax intermedius with no parasites and parasitised by Paracymothoa astyanaxi.

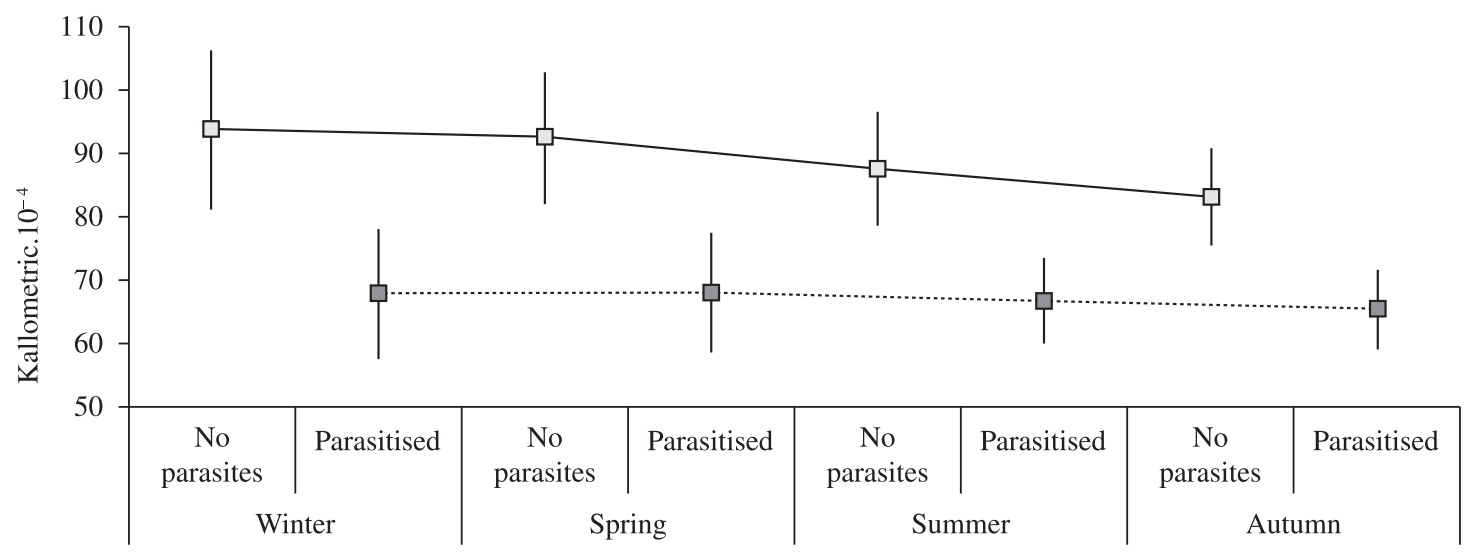

Seasons

Figure 6. Average values of the seasonal allometric condition factor with their standard deviations for Astyanax intermedius with no parasites and parasitised by Paracymothoa astyanaxi. 


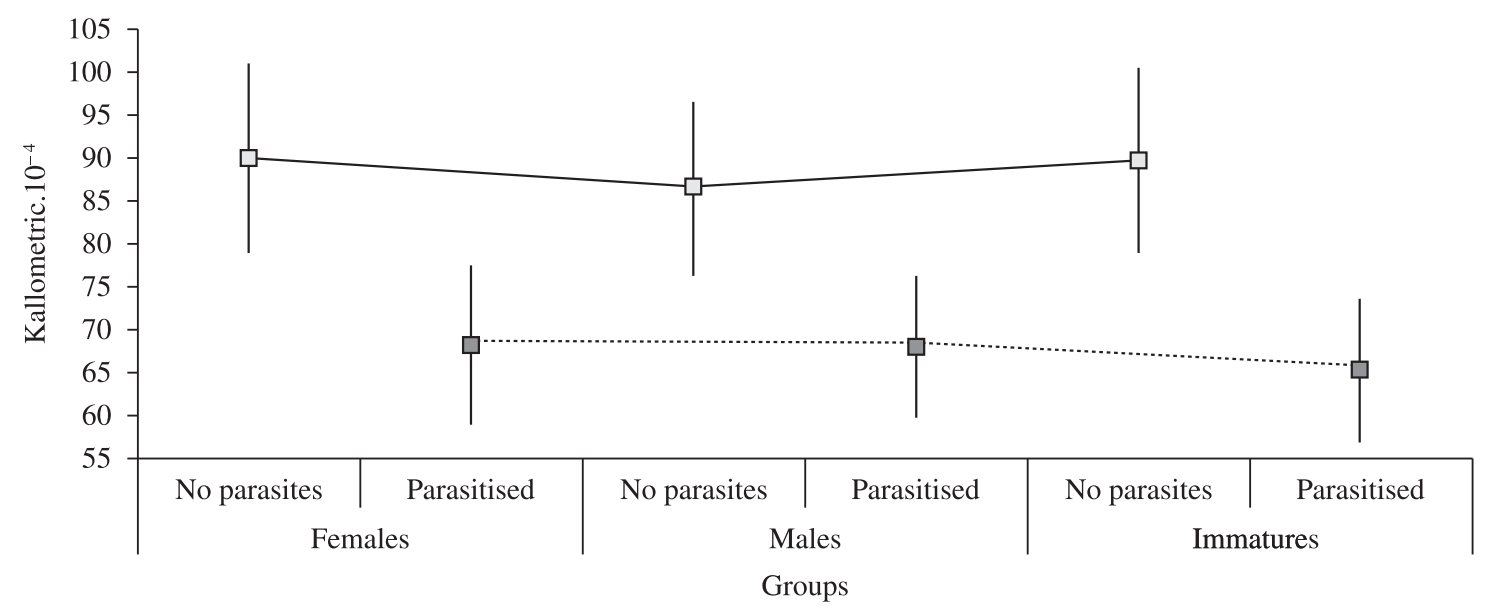

Figure 7. Average values of the allometric condition factor with the standard deviations of females, males and immatures of Astyanax intermedius with no parasites and parasitised by Paracymothoa astyanaxi.


Figure 8. Length-weight relationship of Paracymothoa astyanaxi (a) and average values of the seasonal allometric condition factor with standard deviations of Paracymothoa astyanaxi (b). 
condition factor of winter $(\mathrm{K}=0.0000188)$ was similar ( $p>0.01)$ to autumn $(\mathrm{K}=0.0000187)$ and was lower $(\mathrm{p}<0.05)$ for values of spring $(\mathrm{K}=0.0000232)$ and summer $(\mathrm{K}=0.0000238)$. The values of spring and summer were similar $(p>0.01)$ and higher $(p<0.05)$ than those of values for autumn.

\section{Discussion}

Fish with parasites in the oral region may show morphological changes, including in relation to the size of the tongue. The replacement of the tongue by the parasite may not be highly developed or a required evolutionary strategy, but this substitution is a consequence of the evolutionary pre-adaptation to have a body plan that may be able to play this role (Brusca and Gilligan, 1983).

About $16 \%$ of Astyanax intermedius were parasitised by Paracymothoa astyanaxi, and parasitism increases the susceptibility of fish to predation, and also increases susceptibility to humans (Barber et al., 2000). In the case of parasitism by Cymothoidae, the occurrence may be underestimated by the behaviour of the parasites who abandon the host and so cease swimming movements (Brusca, 1978). These underestimated values were minimised, because most samples were collected with sieves and packaged in formaldehyde.

Abilhoa (2007) found different values of the distribution of lengths between males (5.4 to $6.7 \mathrm{~cm}$ ) and females (6.1 to $8.1 \mathrm{~cm}$ ) of Astyanax scabripinnis. Females were more frequent and larger than males of Astyanax paranae (= A. scabripinnis paranae) (Souza and Moreira-Filho, 1995; Abelha and Goulart, 2008).

There was no difference in length distribution of male and female of A. intermedius parasitised as in Luque et al. (1996), Tavernari et al. (2005), Azevedo et al. (2006) and Lizama et al. (2008) in studies with other species of marine and freshwater fishes. These authors verified that there was no difference in parasitism between males and females or according to the size of the host. If there were significant differences these can be inferred to different behaviours and thus different exposures to parasitism (Guidelli et al., 2003). Parasitism of Scomberomus brasiliensis Collette, Russo and Zavala-Camin (1978) by isopods showed a preference for immature and maturing individuals regardless of the sex, without influence on body condition of hosts (Lima et al., 2005).

In parasites of the family Cymothoidae, sexual dimorphism is common in males which are shorter than females. For the parasite Livoneca sp., youth reach $2 \mathrm{~mm}$ long, females 10 to $16.5 \mathrm{~mm}$ and males 7.5 to $10.2 \mathrm{~mm}$ (Colorni et al., 1997). For P. astyanaxi parasitising Astyanax bimaculatus, the largest female with eggs was $10.5 \mathrm{~mm}$ long and $5 \mathrm{~mm}$ wide, and the smallest was $8 \mathrm{~mm}$ in length and $3 \mathrm{~mm}$ wide (Lemos de Castro, 1955). For the same species parasitising A. intermedius, females were 6.5 to $11.3 \mathrm{~mm}$ and males were 3.2 to $7.6 \mathrm{~mm}$. This variation can be explained by the larger sample of Astyanax intermedius or a change due to the characteristics of the new species parasitised. Being a protandrous species, it was possible to determine the length of the parasites which pass from male to female and changed its behaviour from a free life to a life exclusively parasitic.

The values of seasonal condition factor for specimens without parasites were higher in winter and spring, possibly due to better conditions before the breeding season (winter) as in Astyanax scabripinnis paranae (Barbieri, 1992b) and feeding (spring) (Abilhoa, 2007). In addition, Abelha and Goulart (2008) found that females of Astyanax scabripinnis have higher condition factor than males in the winter months. On the other hand, Barbieri (1992a) stated that the condition factor of A. scabripinnis was highest during the reproductive period in late spring and early summer. Condition factors can vary and corroborate food and/ or breeding conditions of fish in various environments. However, for the condition factor of the specimens no parasites showed seasonal differences, and were greater than the average condition factor of parasitised fishes. In addition, the parasitised fishes showed no differences in average seasonal condition factor. It can be inferred then, that parasitised $A$. intermedius do not have the same biotic conditions of non-parasitised individuals, with values of condition factors being similar throughout the year.

The condition factor of Gymnotus spp. was greater for parasitised individuals (Isaac et al., 2004). However, the condition factor of Gymnotus carapo Linnaeus, 1758 and of Cichlasoma paranaense Kullander, 1983 parasitised by Clinostomum complanatum (Rudolphi, 1814) (Trematoda) did not change compared to non-parasitised individuals (Silva-Souza and Ludwig, 2005). As for Pterodoras granulosus (Valenciennes, 1821) parasitised by Rondonia rondoni Travassos (1920) (Nematoda), for Franciscodoras marmoratus (Reinhardt, 1874) for the São Francisco River (Dias et al., 2004; Santos and Brasil-Sato, 2006) and for Atherinomorus lacunosus (Forster, 1801) parasitised by Livoneca sp. (Cymothoidae) (Colorni et al., 1997), suggesting a stable fish-parasite relationship. However, low body condition is not necessarily a result of parasitism, but fish that are always in poor condition may be more susceptible to parasitism (Barber et al., 2000). Condition factor did not differ significantly between parasitised and non-parasitised individuals of two species of cichlids and of Plagioscion squamosissimus (Heckel, 1840) (Tavernari et al., 2005; Yamada et al., 2008). Eiras (1994) and Varvarigos (2003) highlighted that fishes that have survived parasitism are usually of inferior body condition and have both inferior length and weight when compared with parasitised and non-parasitised fishes.

The energy absorbed by the parasite would often be required for the development of the gonads of the host. The parasitic castration must have some benefit for the parasite, either more growth or success of transmission. In these cases, the individuals of the population who avoid the parasites are favoured by selection. Moreover, individuals without parasites can have benefits in being associated with parasitised fish that cannot feed themselves adequately (Barber et al., 2000). Regarding this, the larger 
the school, the greater the protective effect against predation and for some fish in this school unable to feed themselves sufficiently, the greater are the chances to ensure food.

The condition factor for both sexes in individuals free of parasitism showed that the values of females and immatures was higher than males, as is presented by Abilhoa (2007). On the other hand, Barbieri et al. (1982) verified no differences in condition factor between males and females of Astyanax scabripinnis. The values of condition factor for the groups of females, males and immatures parasitised showed no difference, which corroborate the reasons given for the same result found in different seasons.

The condition factor of the parasites was higher in spring and summer. The population dynamics of parasites show a clear seasonal variation (Simková et al., 2005). Females of Riggia paranensis Szidat (1948) (Cymothoidae) reproduce throughout the year, but show higher percentages of embryos (90\%) developing in the marsupium during the spring-summer (Lima et al., 2007).

The host-parasite relationship appears to be speciesspecific and has all the characteristics of an evolutionary process of adaptive strategies, as the host is able to maintain its feeding ability while the parasites grow to sexual maturity (Brusca and Gilligan, 1983; Colorni et al., 1997). However, in some cases parasitism can be harmful in the population of the host causing changes in the reproductive and food dynamics of parasitised specimens due to low body condition. The presence of large adult isopod parasites in the oral cavity interferes with feeding, causing stress and growth retardation, and predisposition to invasion of bacteria and/or endoparasites (Varvarigos, 2003).

The condition factor of Astyanax intermedius was affected by the parasitic isopod Paracymothoa astyanaxi. The parasite is located in the oral cavity of the host and makes the ingestion of food by parasitised fish difficult, causing them to decline in weight compared with fish without parasites of the same length. This relationship of parasitism can also influence the reproductive activity of the parasitised specimens due to the decrease of stored energy from foods.

Acknowledgements - The authors would like to thank FAPESP for the scholarship conceded to the first author (proc. $\mathrm{n}^{\mathrm{o}}$ 04/12669-3), CNPq for the scholarship conceded to the second author (proc. $\left.\mathrm{n}^{\circ} 140180 / 2005-2\right)$ ), IBAMA (proc. $\mathrm{n}^{\mathrm{o}}$ 02027.000234/2005-05) for authorising the license for the execution of field works, Prof. Dr. Vinicius A. Bertaco (UFRGS) for the identification of fishes and the designer Jaime R. Somera for the confection of drawings.

\section{References}

ABDALLAH, VD., AZEVEDO, RK. and LUQUE, JL., 2004. Metazoários parasitos dos lambaris Astyanax bimaculatus (Linnaeus, 1758), A. parahybae Eigenmann, 1908 e Oligosarcus hepsetus (Cuvier, 1829) (Osteichthyes: Characidae), do rio Guandu, estado do Rio de Janeiro, Brasil. Revista Brasileira de Parasitologia Veterinária, vol. 13 , no. 2, p. 57-63.

ABELHA, MCF. and GOULART, E., 2008. Population structure, condition factor and reproductive period of Astyanax paranae
(Eigenmann, 1914) (Osteichthyes: Characidae) in a small and old brazilian reservoir. Brazilian Archives of Biology and Technology, vol. 51, no. 3, p. 503-512. http://dx.doi.org/10.1590/ S1516-89132008000300009

ABILHOA, V., 2007. Aspectos da história natural de Astyanax scabripinnis Jenyns (Teleostei, Characidae) em um riacho de floresta com araucária no sul do Brasil. Revista Brasileira de Zoologia, vol. 24, no. 4, p. 997-1005. http://dx.doi.org/10.1590/ S0101-81752007000400016

AZEVEDO, JS., GOMES DA SILVA, L., BIZERRIL, CRSF., DANSA-PETRETSKI, M. and LIMA, NRW., 2006. Infestation pattern and parasitic castration of the crustacean Riggia paranensis (Crustacea, Cymothoidea) on the fresh water fish Cyphocharax gilbert (Teleostei, Curimatidae). Neotropical Ichthyology, vol. 4, no. 3, p. 363-369. http://dx.doi.org/10.1590/S1679-62252006000300008

BARBER, I., HOARE, D. and KRAUSE, J., 2000. Effects of parasites on fish behaviour: a review and evolutionary perspective. Reviews in Fish Biology and Fisheries, vol. 10, p. 131-165. http:// dx.doi.org/10.1023/A:1016658224470

BARBIERI, G., 1992a. Biologia de Astyanax scabripinnis paranae (Characiformes, Characidae) do ribeirão do Fazzari. São Carlos. Estado de São Paulo. I. Estrutura populacional e crescimento. Revista Brasileira de Biologia = Brazilian Journal of Biology, vol. 52 , no. 4 , p. 579-588.

-, 1992b. Biologia de Astyanax scabripinnis paranae (Characiformes, Characidae) do ribeirão do Fazzari. São Carlos. Estado de São Paulo. II. Aspectos quantitativos da reprodução. Revista Brasileira de Biologia $=$ Brazilian Journal of Biology, vol. 52, no. 4, p. 589-596.

BARBIERI, G., SANTOS, MVR. and SANTOS, JM., 1982. Época de reprodução e relação peso/comprimento de duas espécies de Astyanax (Pisces, Characidae). Pesquisa Agropecuária Brasileira, vol. 17 , no. 7 , p. $1057-1065$.

BASTOS, PB. and THATCHER, VE., 1997. A redescription of Riggia paranensis Szidat, 1948 (Isopoda, Cymothoidae) based on thirty-two specimens from curimatid fish of Rio de Janeiro, Brazil, with an emendation of the Genus. Memórias do Instituto Oswaldo Cruz, vol. 92, no. 6, p. 755-760. http://dx.doi.org/10.1590/ S0074-02761997000600005

BERTACO, VA. and LUCENA, CAS., 2006. Two new species of Astyanax (Ostariophysi: Characiformes: Characidae) from eastern Brazil, with synopsis of the Astyanax scabripinnis species complex. Neotropical Ichthyology, vol. 4, no. 1, p. 53-60.

BRAGA, FMS., 1986. Estudo entre fator de condição e relação peso-comprimento para alguns peixes marinhos. Revista Brasileira de Biologia = Brazilian Journal of Biology, vol. 46, no. 2, p. 339-346.

-, 1990. Aspectos da reprodução e alimentação de peixes comuns em um trecho do rio Tocantins entre Imperatriz e Estreito, Estados do Maranhão e Tocantins, Brasil. Revista Brasileira de Biologia $=$ Brazilian Journal of Biology, vol. 50, no. 3, p. 547-558.

BRUSCA, RC., 1978. Studies on the Cymothoid fish symbionts of the eastern Pacific (Isopoda, Cymothoidae) I. Biology of Nerocila californica. Crustaceana, vol. 34, no. 2, p. 141-154. http://dx.doi.org/10.1163/156854078X00718

BRUSCA, RC. and GILLIGAN, MR., 1983. Tongue replacement in a marine fish (Lutjanus guttatus) by a parasitic isopod (Crustacea: Isopoda). Copeia, vol. 1983, no. 3, p. 813-816.

COLORNI, A., TRILLES, JP. and GOLANI, D., 1997. Livoneca sp. (Flabellifera: Cymothoidae), an isopod parasite in the oral and branchial cavities of the Red Sea silverside Atherinomorus lacunosus (Perciformes, Atherinidae). Diseases of Aquatic Organisms, vol. 31, p. 65-71. http://dx.doi.org/10.3354/dao031065 
DELARIVA, RL., AGOSTINHO, AA., NAKATANI, K. and BAUMGARTNER, G., 1994. Ichthyofauna associated to aquatic macrophytes in the upper Paraná River floodplain. Revista UNIMAR, vol. 16 , no. 3, p. 41-60.

DIAS, PG., FURUYA, WM., PAVANELLI, GC., MACHADO, MH. and TAKEMOTO, RM., 2004. Carga parasitária de Rondonia rondoni, Travassos, 1920 (Nematoda, Atrictidae) e fator de condição do armado, Pterodoras granulosus, Valenciennes, 1833 (Pisces, Doradidae). Acta Scientiarum, vol. 26, no. 2, p. 151-156.

EIRAS, JC., 1994. Elementos de ictioparasitologia. Porto: Fundação Engenheiro Antonio de Almeida. 327 p.

GOMIERO, LM. and BRAGA, FMS., 2006. Diversity of the ichthyofauna in the Serra do Mar State Park-Núcleo Santa Virgínia, São Paulo state, Brazil. Acta Scientiarum, vol. 28, no. 3, p. 213-218.

GUIDELLI, GM., ISAAC, A., TAKEMOTO, RM. and PAVANELLI, GC., 2003. Endoparasite infracommunities of Hemisorubim platyrhynchos (Valenciennes, 1840) (Pisces: Pimelodidae) of the baía river, upper Paraná River floodplain, Brazil: specific composition and ecological aspects. Revista Brasileira de Biologia $=$ Brazilian Journal of Biology, vol. 63, no. 2, p. 261-268.

ISAAC, A., GUIDELLI, GM., FRANÇA, JG. and PAVANELLI, GC., 2004. Composição e estrutura das infracomunidades endoparasitárias de Gymnotus spp. (Pisces: Gymnotidae) do rio Baía, Mato Grosso do Sul, Brasil. Acta Scientiarum, vol. 26, no. 4, p. 453-462.

LEMOS DE CASTRO, A., 1955. "Paracymothoa astyanaxi" g. n. e sp. n. de isópode parasita de peixe de água doce (Isopoda, Cymothoidae). Revista Brasileira de Biologia = Brazilian Journal of Biology, vol. 15, no. 4, p. 411-414.

LIMA, JTAX., CHELLAPPA, S. and THATCHER, VE., 2005. Livoneca redmanni Leach (Isopoda, Cymothoidae) e Rocinela signata Schioedte \& Meinert (Isopoda, Aegidae), ectoparasitos de Scomberomorus brasiliensis Collete, Russo \& Zavala-Camin (Osteichthyes, Scombridae) no Rio Grande do Norte, Brasil. Revista Brasileira de Zoologia, vol. 22, no. 4, p. 1104-1108. http://dx.doi.org/10.1590/S0101-81752005000400041

LIMA, NRW., AZEVEDO, JS., SILVA, LG. and DANSAPETRETSKI, M., 2007. Parasitic castration, growth, and sex steroids in the freshwater bonefish Cyphocharax gilbert (Curimatidae) infested by Riggia paranensis (Cymothoidea). Neotropical Ichthyology, vol. 5, no. 4, p. 471-478.

LIZAMA, MAP., TAKEMOTO, RM. and PAVANELLI, GC., 2008. Ecological aspects of metazoan parasites of Astyanax altiparanae Garutti \& Britski, 2000 (Characidae) of the Upper Paraná river floodplain, Brazil. Boletim do Instituto de Pesca, vol. 34 , no. 4 , p. $527-533$.

LUQUE, JL., AMATO, JFR. and TAKEMOTO, RM., 1996. Comparative analysis of the communities of metazoan parasites of Orthopristis ruber and Haemulon steindachneri (Osteichthyes: Haemulidae) from the southeastern brazilian littoral: II. Diversity, interspecific associations, and distribution of gastrointestinal parasites. Revista Brasileira de Biologia = Brazilian Journal of Biology, vol. 56, no. 2, p. 293-302.

MOREIRA, ST., ITO, KF., TAKEMOTO, RM. and PAVANELLI, GC., 2005. Ecological aspects of the parasites of Iheringichthys labrosus (Lütken, 1874) (Siluriformes: Pimelodidae) in reservoirs of Paraná basin and upper Paraná floodplain, Brazil. Acta Scientiarum, vol. 27, no. 4, p. 317-322.

MOREIRA-FILHO, O. and BERTOLLO, LAC., 1991. Astyanax scabripinnis (Pisces, Characidae): a species complex. Revista Brasileira de Genética, vol. 14, no. 2, p. 331-357, 1991.

SANTOS, EP., 1978. Dinâmica de populações aplicada à pesca e piscicultura. São Paulo: Hucitec EdUSP. 129 p.
SANTOS, MD. and BRASIL-SATO, MC., 2006. Parasitic community of Franciscodoras marmoratus (Reinhardt, 1874) (Pisces: Siluriformes, Doradidae) from the upper São Francisco river, Brazil. Revista Brasileira de Biologia = Brazilian Journal of Biology, vol. 66, no. 3, p. 931-938.

SILVA-SOUZA, AT. and LUDWIG, G., 2005. Parasitism of Cichlasoma paranaense Kullander, 1983 and Gymnotus carapo Linnaeus, 1814 by Clinostomum complanatum (Rudolphi, 1814) metacercariae in the Taquari river. Revista Brasileira de Biologia $=$ Brazilian Journal of Biology, vol. 65, no. 3, p. 513-519.

SIMKOVÁ, A., JARKOVSKY, J., KOUBKOVÁ, B., BARUS, V. and PROKES, M., 2005. Associations between fish reproductive cycle and the dynamics of metazoan parasite infection. Parasitological Resources, vol. 95, p. 65-72. PMid:15565460. http://dx.doi. org/10.1007/s00436-004-1261-y

SOUZA, IL. and MOREIRA-FILHO, O., 1995. Cytogenetic diversity in the Astyanax scabripinnis species complex (Pisces, Characidae) I. Allopatric distribution in a small stream. Cytologia, vol. 60 , p. 1-11.

TAVARES, LER. and LUQUE, JL., 2004. Community ecology of metazoan parasites of the later juvenile common snook Centropomus undecimalis (Osteichthyes: Centropomidae) from the coastal zone of the state of Rio de Janeiro, Brazil. Revista Brasileira de Biologia = Brazilian Journal of Biology, vol. 64, no. 3A, p. 523-529.

TAVERNARI, FC., BELLAY, S., TAKEMOTO, RM., GUIDELLI, GM., LIZAMA, MAP. and PAVANELLI, GC., 2005. Ecological aspects of Diplectanum piscinarius (Platyhelminthes, Monogenea) parasite of gills of Plagioscion squamosissimus (Osteichthyes, Sciaenidae) in the Upper Paraná River floodplain, Brazil. Acta Scientiarum, vol. 27, no. 3, p. 225-229.

THATCHER, VE., 1991. Amazon fish parasites. Amazoniana, vol. 11, n. 3/4, p. 263-572.

-, 1993. Anphira branchialis gen. et sp. nov. (Crustacea, Isopoda, Cymothoidae) a gill cavity parasite of piranhas (Serrasalmus spp.) in the brazilian Amazon. Acta Amazonica, vol. 23, n. 2-3, p. 297-307.

VANZOLINI, PE., 1993. Métodos estatísticos elementares em sistemática zoológica. São Paulo: Hucitec. 130 p

VARVARIGOS, P., 2003. Parasitic isopods (suborder Flabellifera) affecting the farmed marine fish in Greece, with special reference to Ceratothoa oestroides (family Cymothoidae). Veterinary Services to Aquaculture and Distribution of Fish Health Products. Available from: <http://www.vetcare.gr/Pathogenic_isopoda.htm>.

VILELLA, FS., BECKER, FG. and HARTZ, SM., 2002. Diet of Astyanax species (Teleostei, Characidae) in an Atlantic forest river in Southern Brazil. Brazilian Archives of Biology and Technology, vol. 45, no. 2, p. 223-232. http://dx.doi.org/10.1590/ S1516-89132002000200015

YAMADA, FH., TAKEMOTO, RM. and PAVANELLI, GC., 2008. Relação entre fator de condição relativo (Kn) e abundância de ectoparasitos de brânquias, em duas espécies de ciclídeos da bacia do rio Paraná, Brasil. Acta Scientiarum, vol. 30, no. 2, p. 213-217.

ZAR, JH., 2010. Biostatistical analysis. 3rd ed. New Jersey: Prentice-Hall International Editions. 944 p. 